\title{
Alternate wetting and drying irrigation for rice cultivation
}

\author{
M.M.H. Oliver ${ }^{1}$, M.S.U. Talukder and M. Ahmed \\ Department of Irrigation and Water Management, Bangladesh Agricultural University, Mymensingh- \\ 2202, Bangladesh \\ ${ }^{1}$ Department of Agricultural Engineering, Bangabandhu Sheikh Mujibur Rahman Agricultural University, \\ Gazipur-1706, Bangladesh
}

\begin{abstract}
A field experiment was conducted at the Bangladesh Agricultural University (BAU) to find out possible effects of alternate wetting and drying irrigation (AWDI) on the yield, water use and water use efficiency (WUE) of Boro rice. The experimental layout was furnitured using split-plot design (SPD) with two modern varieties (MV) of rice viz. BRRIdhan 28 and BRRIdhan 29, which received four irrigation treatments randomly and was replicated thrice. The treatments ranged from continuous submergence $\left(T_{1}\right)$ of the field to a number of delayed irrigations $\left(T_{2}, T_{3}\right.$ and $\left.T_{4}\right)$ denoting application of $5 \mathrm{~cm}$ irrigation water when water level in the perforated PVC pipe fell 10, 20 and $30 \mathrm{~cm}$ below ground level (G.L.), respectively. The study revealed that treatment $T_{1}$ attributed by the highest total water use $(122.2 \mathrm{~cm})$ and the lowest WUE $(58.53 \mathrm{~kg} / \mathrm{ha} / \mathrm{cm})$ produced the highest grain yield $(6.86 \mathrm{t} / \mathrm{ha})$. Treatment $\mathrm{T}_{2}$, on the contrary, gave the second highest yield (6.58 t/ha) and consequently the second highest WUE (69.48 $\mathrm{kg} / \mathrm{ha} / \mathrm{cm}$ ) indicating quite a large water saving $(15 \mathrm{~cm})$ compared to treatment $T_{1}$. The yields in treatments $T_{3}(6.27 \mathrm{t} / \mathrm{ha})$ and $\mathrm{T}_{4}(5.86 \mathrm{t} / \mathrm{ha})$ were significantly lower at $1 \%$ level of significance compared to that of treatment $T_{1}$. No significant effect was found either for the treatment or for the varieties on the number of effective and total tillers hill ${ }^{-1}$ nor did they affect 1000 grain weight. Reduced plant height, no. of effective tillers hill ${ }^{-1}$, grain yield, straw yield, biological yield and harvest index were found with the increasing water stress.
\end{abstract}

Key words: Alternate wetting and drying irrigation, Boro rice, Yield, Water use efficiency

\section{Introduction}

Due to increasing scarcity of freshwater resources available for irrigated agriculture and escalating demand of food around the world, in the future, it will be necessary to produce more food with less water. Since, more irrigated land is devoted to rice than to any other crops in the world, wastage of the resource in the rice field should be minimized (IRRI, 2003). For nearly half of the world's population (2.7 billion people), rice is the staple food providing 35-60 percent of the calories consumed (Guerra et al., 1998). More than 75 percent of the world's rice is produced in irrigated rice lands, which are predominantly found in Asia. The abundant water environment in which rice grows best differentiates it from all other important crops. But, water is becoming increasingly scarce. By 2025, the per capita available water resources in Asia are expected to decline by 15-54 percent compared with 1990 (Moya et al., 2001). From time immemorial, rice has been grown in low land areas under flooded conditions. Rice grown under traditional practices in the Asian tropics and subtropics requires between 700 and $1,500 \mathrm{~mm}$ of water for a cropping season depending on soil texture (Bhuiyan, 1992). The actual amount of water used by the farmers for land preparation and during the crop growth period is much higher than the actual field requirement. Paddy farmers often store water in their fields as a back-up safety measure against uncertainty in water supply. Also, there is often field-to-field irrigation. This leads to a high amount of surface runoff, seepage and percolation accounting for about 50 to 80 percent of the total water input to the field (Sharma, 1989). One method to save water in irrigated rice cultivation is the intermittent drying of the rice fields instead of keeping them continuously flooded. This method is referred to as alternate wetting and drying irrigation (AWDI). In certain areas and under the right conditions, AWDI is a promising method in irrigated rice cultivation with dual 
benefits of water saving and human disease control, while maintaining rice yields at least at the same level. However, many factors play a role in determining the success or failure of AWDI. Some of these factors can be influenced, such as irrigation infrastructure and irrigation management capacity, while others cannot be, such as rainfall and soil conditions (Rajendran et al., 1995). The increased productivity of water is likely to be the critical factor that will make farmers and officials adopt AWDI in water-scarce areas. AWDI is one method that can increase the productivity of water at the field level by reducing seepage and percolation during the crop growing period. AWDI is one method of managing the water so that water will not be wasted but it will aid the root growth, facilitate higher nutrient uptake and increase land and water productivity (Sarkar, 2001). Improvisation of the water management techniques adopted by the farmers for the production of Boro rice was the core objective of this study. More specifically, the objective could be outlined as to find out, from a number of AWDI irrigation treatments, the best one with the highest water use efficiency that would result in an insignificant yield loss and ensure the best use of the available water resources.

\section{Materials and Methods}

The Bangladesh Agricultural University Farm of Mymensingh was selected as the experimental site. Topography of the land being plain was suitable for check basin irrigation. Individual plots were located inside a close growing rice field so that actual growing condition (reception of the direct and diffused fluxes) prevails in the site. Soil texture of the experimental site was found to be silty loam. The upper root zone of the experimental field was tilled with high puddling intensity. The experimental plots $(4 \mathrm{~m} \times 2.5 \mathrm{~m})$ were laid out with split-plot design (SPD) combining two modern varieties of rice (BRRIdhan 29 and BRRIdhan 28) and four irrigation treatments that were replicated thrice. This resulted in a total of 24 plots in the field with 8 plots in a row. Each of the plots was separated by $1 \mathrm{~m}$ of transition zone while each of the replications was demarcated by a buffer zone of $1.5 \mathrm{~m}$ in between. To prevent seepage, polythene sheets were pushed into the edges of the levees along the inner perimeter of all plots. PVC pipes of $4 \mathrm{~cm}$ in diameter and $40 \mathrm{~cm}$ in length were installed in the field keeping $7 \mathrm{~cm}$ above the soil and the remaining $33 \mathrm{~cm}$ which was perforated underneath to measure the depletion of soil water in the field. Irrigation water was applied when depleting water table inside the pipe reached a certain level. The first treatment $\left(T_{1}\right)$ was continuous submergence (1 to $7 \mathrm{~cm}$ standing water) and the remaining three $\left(T_{2}, T_{3}\right.$ and $\left.T_{4}\right)$ stood for an application of $5 \mathrm{~cm}$ irrigation water when water level in the pipe fell 10, 20 and $30 \mathrm{~cm}$ below the G.L., respectively. Continuous standing water $(5 \mathrm{~cm})$ was maintained in all the plots up to 28 days after transplantation (DAT) to avoid pre-apprehended weed infestation that could be awesome during crop establishment stage. A bowl of 1.5 litres was used to irrigate the plots from the buffer zones by throwing water in. The seedlings were transplanted maintaining hill to hill distance of $15 \mathrm{~cm}$ and row to row distance of $25 \mathrm{~cm}$. The first and the last hills were kept at $7.5 \mathrm{~cm}$ away from their nearest levees resulting in 25 hills along the length and 10 hills along the width. Since the grains of BRRIdhan 28 got ripened earlier than the BRRIdhan 29, the former was harvested (01 May 2008) two weeks earlier than the harvesting date (May 14,2008 ) of the latter. Matured plants inside $1 \mathrm{~m}$ square of land were harvested for subsequent analysis. Moisture content of the grains, however, was adjusted to $14 \%$ equivalent moisture content after measuring through digital grain moisture meter for subsequent analysis. Quantitative information related to yield and all the yield contributing characters viz. plant height, effective tillers, length of the panicle, no. of spikelets per panicle, no. of filled and unfilled grains per panicle, 1000 grain weight, grain yield, straw yield, harvest index and water use efficiency of the two varieties (BRRIdhan 28 and BRRIdhan 29) were analysed to obtain the effect for AWDI on rice production. 


\section{Results and Discussion}

Significant consequences of AWDI on the production of Boro rice were observed as given in Tables 1, 2 and 3 . The highest plant height $(89.6 \mathrm{~cm})$ was obtained in treatment $T_{1}$ (continuous submergence) and the lowest $\left(82.7 \mathrm{~cm}\right.$ ) in $T_{2}$ (applying irrigation after $30 \mathrm{~cm}$ depletion of W.L. below G.L). It was found that increasing water stress significantly resulted in a decrease of plant height. Insignificant varietal and interaction effects were recorded on the number of effective, non effective and total tillers hill ${ }^{-1}$ and length of the panicle as did the treatments except for the number of effective tillers (Table 1). Delayed irrigation also caused reduced number of spikelets in the panicles counting to be the highest (194.33) in treatment $\mathrm{T}_{1}$ and the lowest (177.17) in treatment $\mathrm{T}_{4}$. Significant effects of variety, treatment, and their interaction on the number of filled grains per panicle were also obtained where a decreasing number of filled grains were found as the water stress increased (Table 1, $2 \& 3$ ). Thousand grain weight (1000 grain weight), as it is called the test weight of the desired crop, was significantly affected by the interaction between varieties and treatments though the effect of treatment alone on this parameter remained insignificant at $1 \%$ level of probability (Table 1 ).

Table 1. Yield and yield contributing characters of BRRIdhan $28\left(v_{1}\right)$ and BRRIdhan 29 $\left(v_{2}\right)$ under different irrigation treatments

\begin{tabular}{|c|c|c|c|c|c|c|c|c|c|c|c|c|c|}
\hline & $\begin{array}{l}\text { Plant } \\
\text { height } \\
(\mathrm{cm})\end{array}$ & $\begin{array}{c}\text { No. of } \\
\text { effective } \\
\text { tillers } \\
\text { hill-1 }\end{array}$ & $\begin{array}{l}\text { No. of Non } \\
\text { effective } \\
\text { tillers hill-1 }\end{array}$ & $\begin{array}{c}\text { No. of } \\
\text { total } \\
\text { tillers } \\
\text { hill-1 } \\
\end{array}$ & $\begin{array}{l}\text { Length } \\
\text { of } \\
\text { panicle } \\
(\mathrm{cm})\end{array}$ & $\begin{array}{l}\text { No. of } \\
\text { spikelets } \\
\text { panicle-1 }\end{array}$ & $\begin{array}{c}\text { No. of } \\
\text { filled } \\
\text { grains } \\
\text { panicle-1 }\end{array}$ & $\begin{array}{c}\text { No. of } \\
\text { unfilled } \\
\text { spikelets } \\
\text { panicle-1 }\end{array}$ & $\begin{array}{c}1000 \\
\text { Grain } \\
\text { weight } \\
(\mathrm{gm})\end{array}$ & $\begin{array}{l}\text { Grain } \\
\text { yield } \\
\text { (t/ha) }\end{array}$ & $\begin{array}{l}\text { Straw } \\
\text { yield } \\
\text { (t/ha) }\end{array}$ & $\begin{array}{c}\text { Dry } \\
\text { matter } \\
\text { yield } \\
\text { (t/ha) }\end{array}$ & $\mathrm{HI} \%$ \\
\hline $\mathrm{T}_{1}$ & $89.6^{a}$ & $10.00^{a}$ & 3.17 & 13.17 & 24.43 & 194.33a & $186.67 \mathrm{a}$ & 7.67 & 21.64 & $6.86^{a}$ & $11.20^{a}$ & $18.06^{a}$ & $37.91^{\mathrm{b}}$ \\
\hline $\mathrm{T}_{2}$ & $87.13^{b}$ & $8.67^{\mathrm{b}}$ & 3.33 & 12.00 & 24.88 & $183.67^{b}$ & $177.17^{\mathrm{b}}$ & 6.5 & 21.8 & $6.58^{\mathrm{b}}$ & $9.89^{b}$ & $16.47^{b}$ & $40.1^{a}$ \\
\hline $\mathrm{T}_{3}$ & $84.28^{c}$ & $7.33^{c}$ & 3.33 & 10.67 & 24.47 & $179.50^{\circ}$ & $172.5^{c}$ & 7 & 21.95 & $6.27^{c}$ & $9.47^{c}$ & $15.73^{c}$ & $39.81^{a}$ \\
\hline $\mathrm{T}_{4}$ & $82.7^{\mathrm{d}}$ & $6.00^{\mathrm{d}}$ & 3.33 & 9.33 & 21.77 & $177.17^{\mathrm{d}}$ & $168.3^{d}$ & 8.83 & 21.57 & $5.86^{d}$ & $8.95^{\mathrm{d}}$ & $14.82^{\mathrm{d}}$ & $39.75^{\mathrm{a}}$ \\
\hline$S(x)$ & 0.11 & 0.35 & 0.2 & 7.81 & 1.67 & 0.66 & 0.63 & 0.81 & 0.31 & 0.01 & 0.05 & 0.06 & 0.13 \\
\hline LS & ** & ** & NS & NS & NS & ** & ** & NS & NS & ** & $\star *$ & ** & ** \\
\hline LSD & 0.34 & 1.09 & - & - & - & 2.03 & 1.93 & - & - & 0.0398 & 0.1640 & 0.1734 & 03978 \\
\hline
\end{tabular}

Common letters within the column do not differ statistically either at $1 \%$ or $5 \%$ level of probability (analyzed using MSTAT)

$$
\begin{aligned}
& * * \quad=\text { Statistically significant at } 1 \% \text { level of probability } \\
& \text { NS }=\text { Non significant at either } 1 \% \text { or } 5 \% \text { level of probability } \\
& \text { LS }=\text { Level of significance }
\end{aligned}
$$

\begin{tabular}{|c|c|c|c|c|c|c|c|c|c|c|c|c|c|}
\hline Variety & $\begin{array}{l}\text { Plant } \\
\text { height } \\
(\mathrm{cm})\end{array}$ & $\begin{array}{l}\text { No. of } \\
\text { effective } \\
\text { tillers } \\
\text { hill-1 }^{-1}\end{array}$ & $\begin{array}{c}\text { No. of } \\
\text { non } \\
\text { effective } \\
\text { tillers hill-1 }\end{array}$ & $\begin{array}{c}\text { No. of } \\
\text { total } \\
\text { tillers } \\
\text { hill-1 }^{-1} \\
\end{array}$ & $\begin{array}{l}\text { Length } \\
\text { of } \\
\text { panicle } \\
\text { (cm) }\end{array}$ & $\begin{array}{l}\text { No. of } \\
\text { spikelets } \\
\text { panicle-1 }\end{array}$ & $\begin{array}{l}\text { No. of } \\
\text { filled } \\
\text { grains } \\
\text { panicle-1 }\end{array}$ & $\begin{array}{l}\text { No. of } \\
\text { unfilled } \\
\text { spikelets } \\
\text { panicle-1 }\end{array}$ & $\begin{array}{c}1000- \\
\text { grain } \\
\text { weight } \\
\text { (gm) }\end{array}$ & $\begin{array}{l}\text { Grain } \\
\text { yield } \\
\text { (t/ha) }\end{array}$ & $\begin{array}{l}\text { Straw } \\
\text { yield } \\
\text { (t/ha) }\end{array}$ & $\begin{array}{l}\text { Dry } \\
\text { matter } \\
\text { yield } \\
\text { (t/ha) } \\
\end{array}$ & HI \% \\
\hline V1 & 86.22 & 7.33 & 3.5 & 10.83 & 23.52 & $160.75^{b}$ & $154.83^{b}$ & $5.92^{b}$ & 21.63 & $5.51^{b}$ & $8.40^{\mathrm{b}}$ & $13.91^{b}$ & 39.72 \\
\hline V2 & 85.63 & 8.67 & 3.08 & 19.42 & 24.25 & $206.58^{\mathrm{a}}$ & $197.50^{\mathrm{a}}$ & $9.08^{\mathrm{a}}$ & 21.85 & $7.28^{\mathrm{a}}$ & $11.36^{a}$ & $18.63^{\mathrm{a}}$ & 39.06 \\
\hline$S(x)$ & 0.17 & 0.24 & 0.12 & 5.36 & 1.24 & 0.36 & 0.39 & 0.12 & 0.28 & 0.01 & 0.08 & 0.07 & 0.23 \\
\hline LS & NS & NS & NS & NS & NS & ** & ** & $\star *$ & NS & ** & ** & ** & NS \\
\hline
\end{tabular}

Table 2. Yield and yield contributing characters of BRRIdhan $28\left(\mathrm{~V}_{1}\right)$ and BRRIdhan 29 $\left(V_{2}\right)$

Common letters within the column do not differ statistically either at $1 \%$ or $5 \%$ level of probability (analyzed using MSTAT)

$$
\begin{aligned}
& \star * \quad=\text { Statistically significant at } 1 \% \text { level of probability } \\
& \text { NS }=\text { Non significant at either } 1 \% \text { or } 5 \% \text { level of probability } \\
& \text { LS }=\text { Level of significance }
\end{aligned}
$$


Table 3. Mean effect of interaction between varieties and irrigation treatments on the yield and yield contributing characters of BRRIdhan $28\left(V_{1}\right)$ and BRRIdhan29 $\left(\mathrm{V}_{2}\right)$

\begin{tabular}{|c|c|c|c|c|c|c|c|c|c|c|c|c|c|}
\hline & $\begin{array}{l}\text { Plant } \\
\text { height } \\
(\mathrm{cm})\end{array}$ & $\begin{array}{c}\text { No. of } \\
\text { effective } \\
\text { tillers } \\
\text { hill-1 }\end{array}$ & $\begin{array}{c}\text { No. of non } \\
\text { effective } \\
\text { tillers hill-1-1 }\end{array}$ & $\begin{array}{c}\text { No. of } \\
\text { total } \\
\text { tillers } \\
\text { hill-1 }\end{array}$ & $\begin{array}{l}\text { Length } \\
\text { of } \\
\text { panicle } \\
(\mathrm{cm})\end{array}$ & $\begin{array}{l}\text { No. of } \\
\text { spikelets } \\
\text { panicle- }^{-1}\end{array}$ & $\begin{array}{c}\text { No. of } \\
\text { filled } \\
\text { grains } \\
\text { panicle-1 }^{-1}\end{array}$ & $\begin{array}{c}\text { No. of } \\
\text { unfilled } \\
\text { spikelets } \\
\text { panicle-1 }\end{array}$ & $\begin{array}{c}1000 \\
\text { Grain } \\
\text { weight } \\
\text { (gm) }\end{array}$ & $\begin{array}{l}\text { Grain } \\
\text { yield } \\
\text { (t/ha) }\end{array}$ & $\begin{array}{l}\text { Straw } \\
\text { yield } \\
\text { (t/ha) }\end{array}$ & $\begin{array}{c}\text { Dry } \\
\text { matter } \\
\text { yield } \\
\text { (t/ha) }\end{array}$ & $\mathrm{HI} \%$ \\
\hline $\mathrm{V}_{1} \mathrm{~T}_{1}$ & $89.83^{a}$ & 9.00 & 3.67 & 12.67 & 23.43 & $171.00^{\mathrm{d}}$ & $165.00^{d}$ & 6 & $20.15^{c}$ & $5.89 \mathrm{e}$ & $9.89 \mathrm{e}$ & $15.78 \mathrm{e}$ & $37.32^{\mathrm{e}}$ \\
\hline $\mathrm{V}_{1} \mathrm{~T}_{2}$ & $88.20^{b}$ & 7.33 & 3.67 & 11 & 23.4 & $162.00^{\mathrm{e}}$ & $158.33^{\mathrm{e}}$ & 3.67 & 21.89ab & $5.65^{\mathrm{df}}$ & $8.14^{\dagger}$ & $13.79^{f}$ & $41.00^{\mathrm{a}}$ \\
\hline $\mathrm{V}_{1} \mathrm{~T}_{3}$ & $83.85^{e}$ & 7.33 & 3.33 & 10.67 & 23.4 & $155.33^{f}$ & $150.00^{f}$ & 5.33 & $22.33^{a b}$ & $5.27 \mathrm{~g}$ & $8.04^{\dagger}$ & $13.31 \mathrm{~g}$ & $39.6^{b c}$ \\
\hline $\mathrm{V}_{1} \mathrm{~T}_{4}$ & $83.00^{f}$ & 5.67 & 3.33 & 9 & 23.87 & $154.67^{\dagger}$ & $146.00^{\mathrm{g}}$ & 8.67 & $22.13^{a b}$ & $5.22^{\mathrm{g}}$ & 7.539 & $12.75^{h}$ & $40.97^{\mathrm{a}}$ \\
\hline $\mathrm{V}_{2} \mathrm{~T}_{1}$ & $89.37^{a}$ & 11.00 & 2.67 & 13.67 & 25.43 & $217.67^{a}$ & $208.33^{a}$ & 9.33 & $23.13^{a}$ & $7.83^{a}$ & $12.51^{a}$ & $20.34^{a}$ & $38.49^{d}$ \\
\hline $\mathrm{V}_{2} \mathrm{~T}_{2}$ & $86.07^{c}$ & 10.00 & 3.00 & 13 & 26.37 & $205.33^{b}$ & $196.00^{\mathrm{b}}$ & 9.33 & $21.70^{\mathrm{ab}}$ & $7.51^{\mathrm{b}}$ & $11.64^{b}$ & $19.14^{b}$ & $39.21^{\mathrm{c}}$ \\
\hline $\mathrm{V}_{2} \mathrm{~T}_{3}$ & $84.70^{d}$ & 7.33 & 3.33 & 10.67 & 25.53 & $203.67^{b}$ & $195.00^{b}$ & 8.67 & $21.57^{b}$ & $7.27^{c}$ & $10.89^{c}$ & $18.16^{c}$ & $40.02^{b}$ \\
\hline $\mathrm{V}_{2} \mathrm{~T}_{4}$ & $82.40 \mathrm{~g}$ & 6.33 & 3.33 & 40.33 & 19.68 & $199.67^{c}$ & $190.67^{c}$ & 9 & $21.00^{b c}$ & $6.5 d$ & $10.38 d$ & $16.89^{d}$ & $38.52^{\mathrm{d}}$ \\
\hline$S(x)$ & 0.16 & 0.5 & 0.29 & 11.05 & 2.37 & 0.93 & 0.89 & 1.14 & 0.44 & 0.02 & 0.08 & 0.08 & 0.18 \\
\hline LS & ** & NS & NS & NS & NS & $\star *$ & ** & NS & ** & ** & ** & $\star *$ & ** \\
\hline CV & 0.32 & 10.83 & 15.19 & 126.54 & 17.16 & 0.88 & 0.87 & 26.29 & 3.47 & 0.46 & 70.13 & 0.85 & 0.80 \\
\hline LSD & 0.4839 & - & - & - & - & 2.875 & 2.734 & - & 1.343 & 0.0563 & 0.2320 & 0.2452 & 0.5626 \\
\hline
\end{tabular}

Common letters within the column do not differ statistically either at $1 \%$ or $5 \%$ level of probability (analyzed using MSTAT)

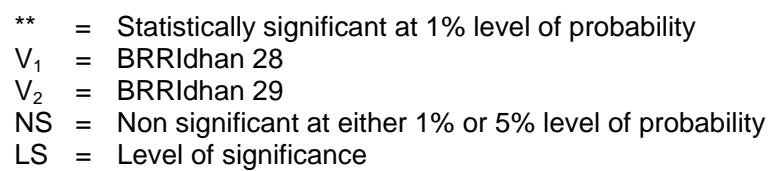

The grain yield, on the other hand, was found to be significantly influenced by different degrees of AWDI irrigation treatments at $1 \%$ level of probability (Table 1 ). The highest and the lowest grain yield was obtained, respectively, in treatment $T_{1}(6.86 \mathrm{t} / \mathrm{ha})$ and $T_{4}$ (5.86 $\mathrm{t} / \mathrm{ha}$ ). Longer water stresses resulted in a loss of grain yield of about $1 \mathrm{t} / \mathrm{ha}$ compared to the grain yield obtained from continuous saturation $\left(T_{1}\right)$. The second highest yield $(6.58 \mathrm{t} / \mathrm{ha})$ was marked in treatment $T_{2}$ (applying irrigation when W.L. depletes $10 \mathrm{~cm}$ below G.L.) which was $95.9 \%$ of the highest yield (6.86 t/ha). Grain yield for the treatment $T_{3}(6.27 \mathrm{t} / \mathrm{ha})$ was $8.66 \%$ less than the highest yield obtained (Table 1). The interaction between the varieties and the treatments, as shown in Table 3, also affected grain yield significantly. The highest yield of BRRIdhan 29 (7.83 t/ha) was obtained for the interaction $\left(V_{2} \times T_{1}\right)$ and the lowest $(5.22 \mathrm{t} / \mathrm{ha})$ for the interaction $\left(V_{1} \times T_{4}\right)$, which was statistically similar to the yield of the interaction $\left(V_{1} \times T_{3}\right)$ (Table 3). For BRRIdhan 29, maximum amount of water $(122.2 \mathrm{~cm})$ was required for $T_{1}$, while, second maximum $(97.2 \mathrm{~cm})$ for $T_{2}$ was followed by the other two treatments, $T_{3}(92.2$ $\mathrm{cm})$ and $T_{4}(87.2 \mathrm{~cm})$. For BRRIdhan 28 the treatments $T_{1}, T_{2}, T_{3}$ and $T_{4}$ required 112.2, 92.2, 87.2 and $82.2 \mathrm{~cm}$ of water, respectively (Table 4).

Table 4. Water use efficiency for different treatments

\begin{tabular}{|c|c|c|c|c|}
\hline \multirow{2}{*}{ Treatments } & \multicolumn{2}{|c|}{ Total water use $(\mathrm{cm})$} & Average total water & Water use efficiency \\
& used $(\mathrm{cm})$ & $\begin{array}{c}\text { Ben } \\
(\mathrm{kg} / \mathrm{ha} / \mathrm{cm})\end{array}$ \\
\hline $\mathrm{T}_{1}$ & 112.20 & 122.20 & 117.2 & 58.53 \\
\hline $\mathrm{T}_{2}$ & 92.20 & 97.20 & 94.7 & 69.48 \\
\hline $\mathrm{T}_{3}$ & 87.20 & 92.20 & 89.7 & 69.89 \\
\hline $\mathrm{T}_{4}$ & 82.20 & 87.20 & 84.7 & 69.19 \\
\hline
\end{tabular}


Water use efficiency (WUE) is the most important criterion to rationalize AWDI practice. The features of total water use and water use efficiency (WUE) came out vivid in the study showing the highest WUE of $69.89 \mathrm{~kg} / \mathrm{ha} / \mathrm{cm}$ of water in treatment $T_{3}$ and the lowest $(58.53$ $\mathrm{kg} / \mathrm{ha} / \mathrm{cm})$ in treatment $T_{1}$. The second highest WUE $(69.48 \mathrm{~kg} / \mathrm{ha} / \mathrm{cm})$ was found in treatment $\mathrm{T}_{2}$ which was much closer to the highest one (Table 4).

The highest average total water $(117.2 \mathrm{~cm})$ used by the plant was found in treatment $T_{1}$ which was also attributed by the highest yield (6.86 t/ha). The treatment $T_{2}$ (applying irrigation after $10 \mathrm{~cm}$ depletion of W.L. below G.L), in spite of using much less amount of water (94.7 $\mathrm{cm}$ ), gave a yield of $6.58 \mathrm{t} / \mathrm{ha}$ which is almost close to the highest yield saving nearly $25 \mathrm{~cm}$ of water compared to treatment $\mathrm{T}_{1}$ (Fig. 1). This clearly demonstrates that submerged paddy field is not necessarily the only solution for optimum production. It was found that it requires 3 to 4 days for $10 \mathrm{~cm}$ depletion of water level below the ground surface in silty-loam soil which, in this study, was termed as $T_{2}$. This practice was found to be the most suitable because of the highest water use efficiency $(69.48 \mathrm{~kg} / \mathrm{ha} / \mathrm{cm})$, insignificant reduction in grain yields $(4.08 \%)$ and water saving $(25 \mathrm{~cm})$. The value of the water saved by this technique would itself be sufficient to arrest the economic justification of the insignificant yield loss in AWDI technique.

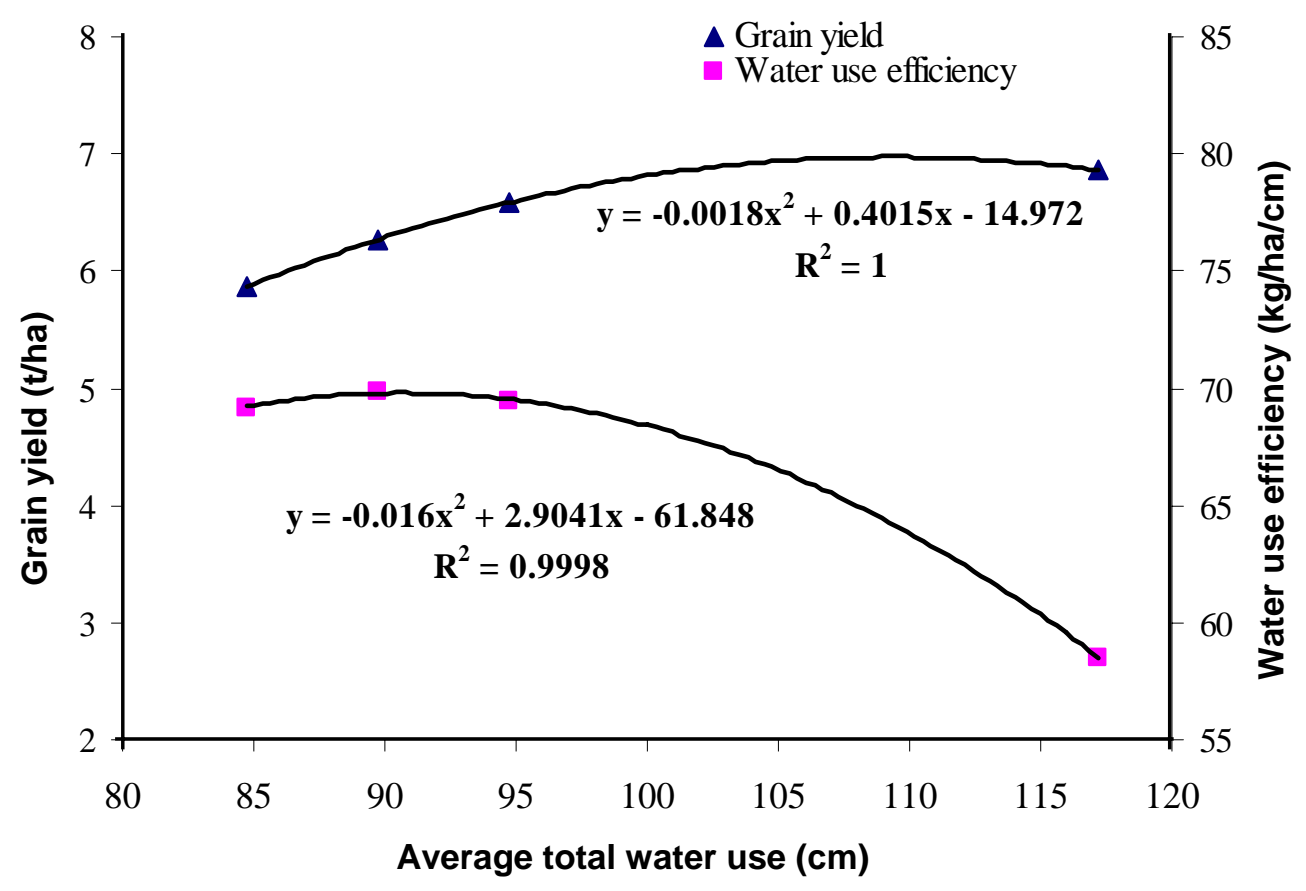

Fig.1. Relation between average total water use with grain yield and water use efficiency 


\section{References}

Bhuiyan, S.I. 1992. Water management in relation to crop production: Case study on rice. Outlook on Agriculture. 21: 293-299.

Guerra, L.C., Bhuiyan, S.I., Tuong T.P. and Barker, R. 1998. Producing more rice with less water from irrigated systems. SWIM Paper 5. Colombo International Irrigation Management Institute, Sri Lanka.

International Rice Research Institute (IRRI). 2003. Annual Report. International Rice Research Institute, Los Banos, Laguna Philippines. p. 125-131.

Moya, P., Hong, L., Dawe, D. and Chen, C.D. 2001. Comparative assessment of on-farm water saving irrigation techniques in the Zhanghe Irrigation System. Water saving irrigation for rice: Proceedings of an International Workshop. Wuhan, China. 81-96.

Rajendran, R., Reuben, R., Purush, S. and Veerapatran, R. 1995. Prospects and problems of intermittent irrigation for control of vector breeding in rice fields in southern India. Annals of Tropical Medicine and Parasitology. 89: 541-549.

Sarkar, S. 2001. Effect of water stress on growth, productivity and water expense efficiency of summer rice. Indian J. Agril. Sci. 71(3): 153-158.

Sharma, P.K. 1989. Effect of periodic moisture stress on water to use efficiency in wet land rice. Oryza. 26: 252-257. 